\title{
Comparative Study of the Phenotypic Structure and Photoperiodic Responses of Female Asian Ladybirds Harmonia axyridis (Pallas) (Coleoptera, Coccinellidae) from Moscow, Belgorod, and Sochi
}

\author{
N. A. Belyakova ${ }^{a}$, A. N. Ovchinnikov ${ }^{a, b}$, O. S. Bezman-Moseyko ${ }^{b}$, and S. Ya. Reznik ${ }^{a, b, *}$ \\ a All-Russia Institute of Plant Protection, Russian Academy of Sciences, Pushkin, St. Petersburg, 196608 Russia \\ ${ }^{b}$ Zoological Institute, Russian Academy of Sciences, St. Petersburg, 199034 Russia \\ *e-mail:reznik1952@mail.ru
}

Received July 16, 2021; revised August 14, 2021; accepted August 14, 2021

\begin{abstract}
Insect invasions are often accompanied by changes in the phenotypic structure of the populations and in the photoperiodic responses that regulate seasonal cycles. The Asian ladybird Harmonia axyridis has been recently discovered in Krasnodar Territory, from whence it is now gradually colonizing Central Russia. Our comparative study of individuals collected in 2020 in Sochi, Belgorod Province, and Moscow Province shows that interpopulation differences in their phenotypic structure are nonsignificant. The proportion of the light morph succinea is $77-83 \%$; the proportion of the most common dark morph, spectabilis, is $13-20 \%$. Laboratory experiments show that females from all the studied populations exhibit only a weak photoperiodic response. Comparative analysis reveals that females from the more northerly Moscow and Belgorod populations have a somewhat greater tendency to diapause and slightly delay reproductive maturation.
\end{abstract}

Keywords: diapause, photoperiod, phenotypic structure, variation, invasions, Harmonia axyridis, Coccinellidae

DOI: $10.1134 / \mathrm{S} 0013873821060014$

The Asian ladybird Harmonia axyridis (Pallas) (Coleoptera: Coccinellidae) is an aggressive invasive aphidophagous species of beetle that is native to East Asia but to date discovered in many countries of Europe, North and South America, and Africa (Roy and Wajnberg, 2008; Lombaert et al., 2010; Brown et al., 2011; Roy et al., 2016). In the Russian Federation, H. axyridis was first recorded on the Black Sea coast of the Northern Caucasus (Korotyaev, 2013; Orlova-Bienkowskaja, 2013; Ukrainsky, 2013; Belyakova and Reznik, 2013) and, since then, it has been gradually moving northward into the center of European Russia (Ukrainsky and Orlova-Bienkowskaja, 2014; Zakharov, 2015; Goryacheva and Blekhman, 2016; Sazhnev et al., 2020). In addition, over the last 2-3 years, invasive populations of the Asian ladybird have been moving eastward up to Ulyanovsk Province and Kazan (Ruchin et al., 2020). Meanwhile, the present-day natural western boundary of the distribution range of $H$. axyridis is located near Yekate- rinburg or, according to some data, is as far west as Ufa (Khabibulin, 2009; Orlova-Bienkowskaja et al., 2015; Andrianov et al., 2018). Thus, nowadays the European and Siberian populations are only 600 to $1000 \mathrm{~km}$ apart. The speed of eastward movement of the European populations suggests that the first contacts between invasive and native ladybirds are likely to occur in a few years. Therefore, it seems worthwhile to assess the peculiarity of invasive European populations of $H$. axyridis before they meet their Siberian conspecifics, in order to have some reference point in the future monitoring of hybridization processes.

The material for this study was selected from the Moscow, Belgorod, and Sochi populations that represented different stages of invasion. In Sochi and Belgorod, this ladybird was discovered over 10 years ago, whereas in Moscow, the first outbreaks were observed in 
2020. Also, these populations originated from different climates.

Our first aim was to quantitatively assess the phenotypic structure of the invasive populations of the Asian ladybird, which is characterized by rich polymorphism in elytral color pattern. Dozens of color morphs of $H$. axyridis are known, underpinned by multiple alleles in a single autosomal locus (Dobzhansky, 1924; Tan, 1946). In the Far East, the light-colored morph succinea predominates, whereas in Siberia, the dark-colored axyridis is the most abundant one. The phenotypic structure of the native populations is remarkably persistent with the frequencies of the more common phenotypes remaining stable for decades (Dobzhansky, 1924; Vorontsov and Blekhman, 1986; Kholin, 1988; Belyakova, 2012; Andrianov et al., 2018). In view of this, it would be quite interesting to quantify the phenotypic structure of the invasive populations.

Another avenue of research addresses photoperiodic responses, which, through the induction of diapause, synchronize the life cycle with seasonal fluctuations in the environment (Danilevskii, 1961; Tyshchenko, 1977; Zaslavskii, 1984; Tauber et al., 1986; Vinogradova, 1991; Denlinger, 2002; Saunders et al., 2002; Saulich and Volkovich, 2004; Danks, 2007; Tougeron, 2019). As a rule, the seasonal cycles of insects are adapted to the local climate, and so dispersion outside the native range is accompanied by the corresponding changes in the main parameters of the photoperiodic response (Saulich, 1999). However, exceptions to this rule also do exist. For example, the broadscale invasion of the Asian ladybird from East Asia to Southern, Western, and Central Europe was accompanied not by adjustment but by attenuation of the photoperiodic response so that the main role in the control of the seasonal cycle was transferred to diet-induced diapause (Reznik et al., 2015).

The objective of this work was to answer two questions: (1) does the phenotypic structure of the populations vary and (2) does the tendency for weaker photoperiodic sensitivity persist as $H$. axyridis is further expanding its distribution in the European part of Russia?

\section{MATERIALS AND METHODS}

The work was carried out with three laboratory colonies of $H$. axyridis that originated from individuals col- lected in the wild in the fall of 2020. The Sochi population was founded by 125 adults collected from overwintering aggregations in a house in Katkova Shchel Village (Lazarevsky District of Greater Sochi, $43.9^{\circ} \mathrm{N}, 39.4^{\circ} \mathrm{E}$ ) in the last third of November 2020. The Belgorod population descended from 133 adults collected from overwintering aggregations in a house in the town of Shebekino (Belgorod Province, $50.4^{\circ} \mathrm{N}$, $36.9^{\circ} \mathrm{E}$ ) in the second third of October 2020. The Moscow population originated from 184 adults, pupae, and late-instar larvae collected from trees and shrubs during an outbreak in the town of Ramenskoe $\left(55.6^{\circ} \mathrm{N}\right.$, $\left.38.2^{\circ} \mathrm{E}\right)$ and the village of Bolshie Vyazemy $\left(55.6^{\circ} \mathrm{N}\right.$, $37.0^{\circ} \mathrm{E}$ ), both in Moscow Province, in the second third of October 2020.

The phenotypic structure was only studied in field-collected individuals. The adults were sorted by the elytral pattern and the following morphs were identified: succinea (hereinafter referred to as SUC), conspiqua (CON), and axyridis (AXY) (Dobzhansky, 1924). To compare the populations of different geographic origin by their phenotypic structure, a metric of population similarity was calculated as

$$
r=\sqrt{ } p_{1} q_{1}+\sqrt{ } p_{2} q_{2}+\ldots+\sqrt{ } p_{\mathrm{n}} q_{\mathrm{n}}
$$

where $p_{1}, p_{2} \ldots p_{\mathrm{n}}$ are morph frequencies in the first population (or sample), expressed as fractions, and $q_{1}$, $q_{2} \ldots q_{\mathrm{n}}$ are frequencies of the respective morphs in the second population (or sample) (Zhivotovsky, 1991). These calculations were performed with Microsoft Excel 2010.

Photoperiodic responses. Prior to the experiments, ladybirds were reared on wheat aphids Schizaphis graminum Rond. (Hemiptera, Aphididae) at a temperature of $20-25^{\circ} \mathrm{C}$ and under a daylength of $18 \mathrm{~h}$. The insects were thus maintained for 2 or 3 generations in the Laboratory of Biomethod of the All-Russia Institute of Plant Protection. The experiments were carried out in the Laboratory of Experimental Entomology of Zoological Institute (Russian Academy of Sciences). All the experimental larvae were kept at $25^{\circ} \mathrm{C}$ under a $14-\mathrm{h}$ light and fed on peach aphids Myzus persicae (Sulz.), which in turn were reared on germinated beans of Vicia faba L. Ladybird pupae were kept under the same conditions. Newly emerged adults, no more than $24 \mathrm{~h}$ old, were transferred to plastic Petri dishes $60 \mathrm{~mm}$ in diameter and $15 \mathrm{~mm}$ tall and allocated among the following 
photoperiodic regimens (light:dark, h): 10L : 14D, 12L : $12 \mathrm{D}, 14 \mathrm{~L}: 10 \mathrm{D}$, and $16 \mathrm{~L}: 8 \mathrm{D}$. The temperature of $25^{\circ} \mathrm{C}$ was the same for all photoperiods.

During the experiments, adult beetles were fed on frozen eggs of grain moth Sitotroga cerealella (Oliv.) (Lepidoptera, Gelechiidae), which were glued onto a piece of cardboard by means of $30 \%$ sucrose solution. Also, in each Petri dish there was a plastic tube filled with water and stoppered with a cotton plug. Relative air humidity was the same in all the regimens (70\%) and food was provided ad libitum. All the Petri dishes were examined daily and the date of the first oviposition was recorded. At the end of the experiment (after 20 days) all the females that had not started egg-laying were dissected. This female age for dissection was chosen based on our previous studies where most nondiapausing females had started producing eggs by the 20th day under long-day conditions (Reznik et al., 2015). During dissection, the condition of the ovaries and that of the fat body were assigned a rank out of four as follows.

Stages of ovary development: 1 - undeveloped (follicles indistinct, their width not exceeding the germarium width); 2-weakly developed (oocytes proceeding into the vitellarium and growing, but follicles still transparent); 3-mid-developed (follicles conspicuous, opaque); and 4-fully developed (eggs present in ovaries).

Stages of fat body development: 1 - undeveloped (fat body transparent, almost indistinct; the viscera and the inner surface of abdominal tergites clearly visible); 2-weakly developed (fat body tissue represented by small globules that partially fill the body cavity); 3 -mid-developed (fat body tissue sheath-like, consisting of globules that form numerous lobes); and 4fully developed (fat body tissue consisting of large globules with inclusions, occupying the whole abdominal volume, the viscera completely hidden in the folds of the fat body).

Classifications like these were used in our previous studies (Reznik et al., 2021) as well as in the works of many other authors (Vaghina, 1974; Kono, 1982; Sakurai et al., 1992; Osawa, 2005; Esquivel, 2011; Musolin, 2012; Raak-van den Berg et al., 2012; Gao et al., 2019).
In total, 689 females were tested in the experiments (no less than 50 per population per photoperiod). Individuals that died during the experiments were discarded. Statistical processing of the results included correlation analysis, analysis of variance, probit analysis, and chisquared test. All computations were performed with SYSTAT 10.2 software.

\section{RESULTS AND DISCUSSION}

Phenotypic structure. There were no significant differences in the phenotypic structure between the samples tested. Pairwise comparisons yielded similarity coefficients that ranged from 0.994 to 0.998 . In all the populations (Sochi, Belgorod, and Moscow), the light-colored morph SUC predominated at frequencies of $77-83 \%$ (Fig. 1). Among the dark-colored morphs, SPC was the most abundant (13-20\%). The frequency of CON never exceeded 2-4\%. The morph AXY, which is rare in Europe, was represented by a single specimen from the Belgorod population.

These data suggest that, in terms of phenotypic composition, the Belgorod, Sochi, and Moscow populations are similar to invasive Western European ones as well as to native Far Eastern populations, the latter being the initial source of invaders (Lombaert et al., 2010). In Western Europe, the frequency of light-colored SUC individuals varies from 70 to $97 \%$, irrespective of climate, season (sampling date) or biotope parameters (Adriaens et al., 2008; Brown et al., 2008; Honěk et al., 2020). Similar frequencies of morphs are reported from remote regions with different climate, e.g., Spain, Great Britain, and Italian Alps, where SUC constitutes $78-79 \%$ of the population (Honěk et al., 2020). In Belarus (Grodno, Brest Province, and Minsk), SUC strongly predominates at $96-97 \%$ (Kruglova et al., 2020), whereas, in adjacent Belgorod Province of Russia, according to our data, the frequency of this morph is lower at $83 \%$ (Fig. 1). In the southeast of the European distribution range of $H$. axyridis, the frequency of SUC is $70-80 \%$ in Kiev (Nekrasova and Titar, 2016), 80-89\% in Crimea (Zakharov and Romanov, 2017), about $80 \%$ in the lowland of Krasnodar Territory (Orlova-Bienkowskaja, 2014), and, according to our results, $82 \%$ in Sochi (Fig. 1). Overall, the macrogeographic variability of the phenotypic composition of $H$. axyridis populations across its invasive European range is greater than in the native Far Eastern 
- AXY $\mathrm{CON} \mathbb{B} \mathrm{SPC} \square \mathrm{SUC}$

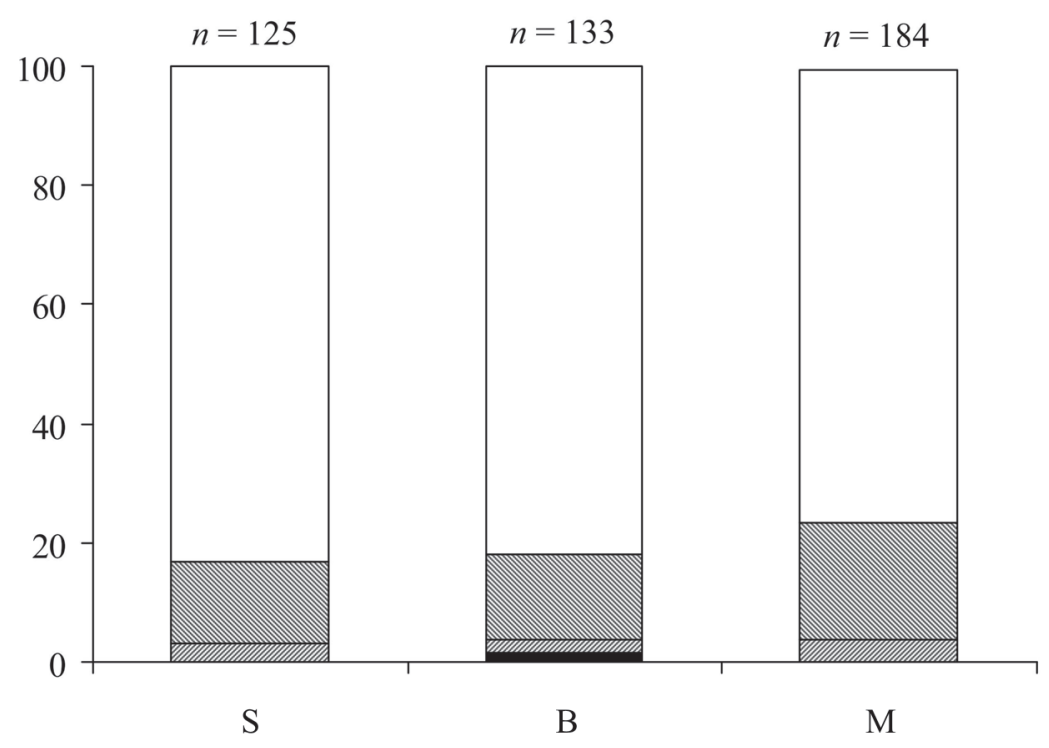

Fig. 1. Phenotypic structure of the Sochi, Belgorod, and Moscow populations of Harmonia axyridis (Pall.). Abscissa, population (S-Sochi; B-Belgorod, M-Moscow); ordinate, morph frequency (\%) (AXY-axyridis, CON—conspiqua, SPC-spectabilis, SUC-succinea). Numbers above columns denote sample size.

populations where SUC steadily predominates at 8590\% for decades (Kholin, 1990; Belaykova, 2011).

Photoperiodic responses. Preliminary analysis of the results of dissection showed that the degree of ovary development was negatively correlated with the degree of fat body development (Spearman's $r=-0.898$, $N=689, p<0.001$ ), as expected. For purposes of further analysis, all the females were divided into four groups (Table 1). Females with undeveloped or weakly developed ovaries and mid- or fully developed fat body were considered as being in diapause. All the females with fully developed ovaries (which were in the majority) were considered as being reproductively active. Females with mid-developed ovaries were regarded as being in the intermediate (transitory) condition. Finally, occasional individuals with both the ovaries and fat body undeveloped or weakly defined were deemed as being maldeveloped, starved or unhealthy and thus were excluded from analysis.

Probit analysis of the whole dataset (Table 2) showed that photoperiod significantly influenced the diapausing-to-active female ratio. As the regression coefficients indicate, the fraction of diapausing females was lower and that of active females higher under long-day conditions as compared with short-day conditions. However, the photoperiodic responses that controlled reproductive

Table 1. Development of the ovaries and the fact body in Harmonia axyridis (Pall.) females that are in different reproductive condition ( $\%$ of the total number of females developing under all photoperiodic regimes, $n=689$ )

\begin{tabular}{l|c|c|c|c}
\hline \multirow{2}{*}{\multicolumn{1}{c|}{ Ovaries }} & \multicolumn{3}{c}{ Fat body } \\
\cline { 2 - 5 } & undeveloped & weakly developed & mid-developed & fully developed \\
\hline Undeveloped & $1.3 \%$ - excluded from further analysis & $20.8 \%$ diapausing \\
Weakly developed & & \\
Mid-developed & $5.9 \%$-intermediate (transitory) condition \\
Fully developed & \multicolumn{3}{|c}{$72.0 \%$-reproductively active } \\
\hline
\end{tabular}




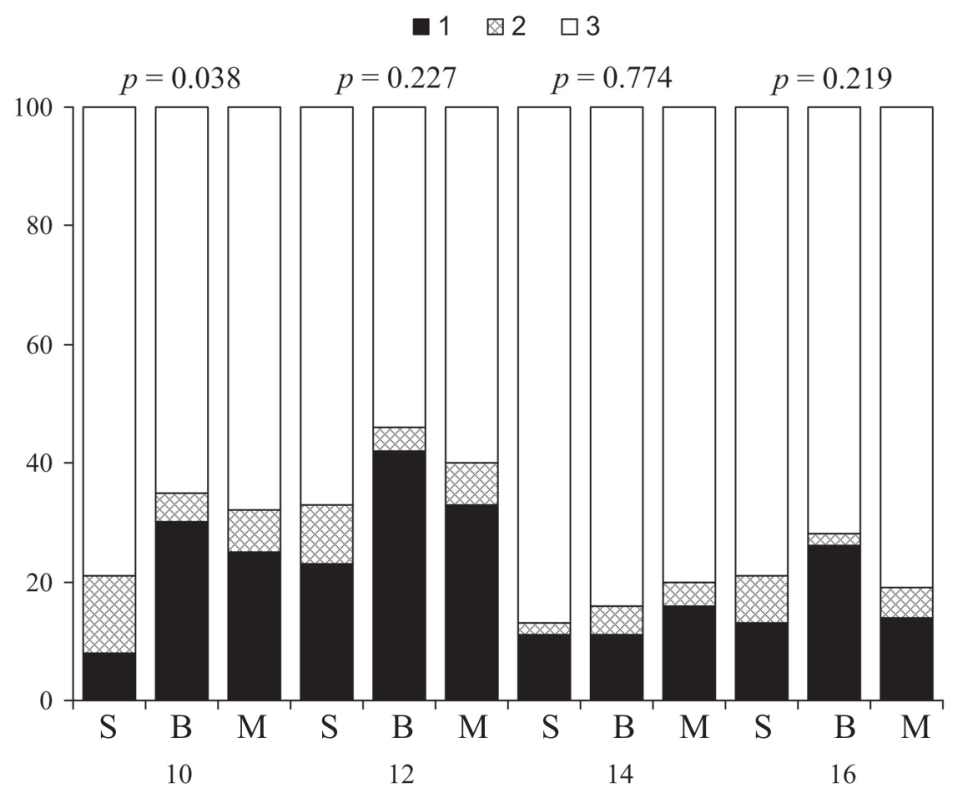

Fig. 2. Percentage of females from the Sochi, Belgorod, and Moscow populations of Harmonia axyridis (Pall.) in different reproductive states as affected by photoperiod. Abscissa, upper line, population (S-Sochi; B-Belgorod, M-Moscow); abscissa, lower line, photoperiod (daylength in h); ordinate, fraction of females in \% (1- diapausing, 2-transitory, 3-reproductively active). Numbers above columns show the significance of differences between populations within each photoperiod according to a chi-squared test.

activity were relatively weak in females from all of the populations studied (Fig. 2). The fraction of reproductively active individuals significantly increased under long-day conditions in Belgorod $(p=0.006)$ and Moscow females $(p=0.034)$ only, while in the Sochi population, the significance of this photoperiodic effect was slightly below the threshold $(p=0.073)$.

The interpopulational differences were also generally weak and only observed for the fraction of diapausing females: individuals from the northern population entered diapause slightly more often (the difference was marginally significant). Separate analyses showed that, within each photoperiod, interpopulational differences were only significant in the short-day regimen (10L:14D): the fraction of diapausing females was higher and that of active females lower in the Belgorod and Moscow populations than in the Sochi population (Fig. 2).

The vast majority ( $85 \%$ ) of reproductively active females commenced oviposition during the experiment. A two-way ANOVA of the entire dataset $(n=429)$ showed that maturation time (measured from adult eclosion to the first egg laid) highly significantly depended on the photoperiod $(F=7.2, d f=3, p<0.001)$. The differences between the populations were much less significant $(F=3.6, d f=2, p=0.029)$ and the interaction of

Table 2. The effects of photoperiod and geographic origin (population) on the percentage of Harmonia axyridis (Pall.) females in different reproductive states (results of probit analysis: regression coefficient $C$, its standard error, and significance $p$; $n=680)$

\begin{tabular}{l|c|c|c}
\hline \multirow{2}{*}{\multicolumn{1}{c}{ Factors and codes }} & \multicolumn{3}{c}{ Females } \\
\cline { 2 - 4 } & diapausing & transitory & active \\
\hline Photoperiod (daylength) & $C=-0.054 \pm 0.025$, & $C=-0.053 \pm 0.034$, & $C=0.067 \pm 0.023$, \\
& $p=0.028$ & $p=0.125$ & $p=0.004$ \\
Population (1-Sochi, 2-Belgorod, & $C=0.135 \pm 0.067$, & $C=-0.116 \pm 0.093$, & $C=-0.073 \pm 0.063$, \\
3-Moscow) & $p=0.046$ & $p=0.213$ & $p=0.253$ \\
\hline
\end{tabular}




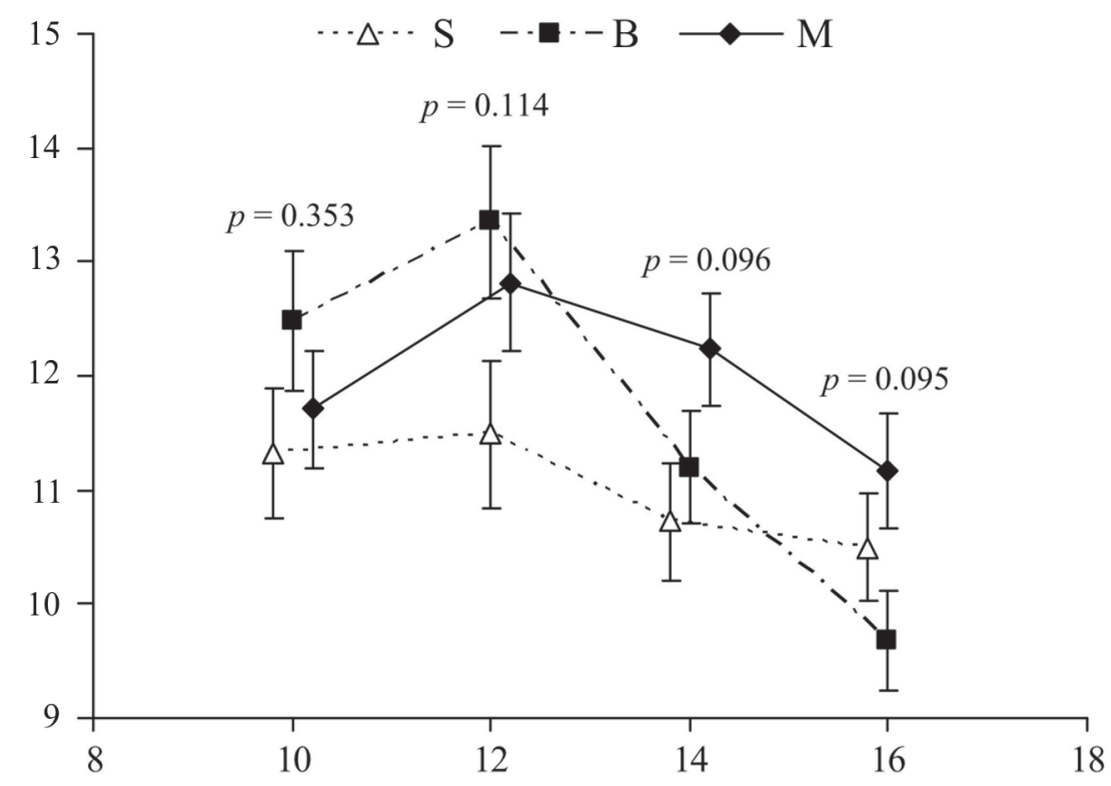

Fig. 3. Maturation time in ovipositing females from the Sochi, Belgorod, and Moscow populations of Harmonia axyridis (Pall.) as affected by photoperiod. Abscissa, daylength (h); ordinate, time from eclosion to the first egg laid by females from different populations (S-Sochi; B-Belgorod, M-Moscow; shown are the means with standard errors). Numbers above symbols show the significance of differences between populations within each photoperiod according to one-way ANOVA.

these factors was nonsignificant $(F=1.5, d f=6$, $p=0.173$ ). As can be seen in Fig. 3, females from Sochi generally maturated somewhat faster than those from Belgorod and Moscow, but the significance of this difference in each particular photoperiodic regimen was below the threshold. Maturation time was shorter under long-day conditions in females from all the populations but one-way ANOVA confirmed the significance of this effect only in the Belgorod population $(F=7.6, d f=3$, $N=126, p<0.001)$, but not in the Sochi $(F=0.7$, $d f=3, N=156, p=0.533)$ or Moscow $(F=1.7, d f=3$, $N=147, p=0.181$ ) ones.

Geographic variation in the properties of photoperiodically induced diapause across different populations has often been the focus of study in numerous insect species from various orders. In most cases, there exist substantial differences that are correlated, to a varying extent, with climatic variables. Often, there is a clinal pattern in the parameters of the photoperiodic response. Studies on widespread insect species even led to a generalization that, with a $5^{\circ}$ change in latitude, the critical photoperiod for diapause induction changes by an average of $1.5 \mathrm{~h}$ (Danilevskii, 1961; Tyshchenko, 1977; Zaslavskii, 1984; Tauber et al., 1986; Vinogra- dova, 1991; Denlinger, 2002; Saunders et al., 2002; Saulich and Volkovich, 2004; Danks, 2007).

A number of studies on the intraspecific variation in the photothermic control of diapause were carried out with coccinellid species (Hodek, 2012). For example, there is a dramatic difference in the photoperiodic response of female Chilocorus bipustulatus L. from Leningrad Province and Middle Asia (Zaslavskii, 1970). Substantial differences were also discovered between populations of Coccinella septempunctata L. that are much closer to each other: beetles from Honshu Island, as a rule, undergo summer diapause, which is never the case in slightly more northerly beetles from Hokkaido (Ohashi et al., 2003). A comparative study of photoperiodic induction of winter diapause in populations of Hippodamia parenthesis (Say) between 40 and $44^{\circ} \mathrm{N}$ in the USA also revealed substantial intraspecific variation (Obrycki, 2020). By contrast, no significant differences in the photoperiodic response were found between the populations of Propylea quatuordecimpunctata (L.) from Canada, Turkey, and southern France (Obrycki et al., 1993).

ENTOMOLOGICAL REVIEW Vol. 101 No. 62021 
The northernmost and southernmost of the studied populations of $H$. axyridis (Moscow and Sochi, respectively) are located $1300 \mathrm{~km}$ apart, which corresponds to a $12^{\circ}$ difference in latitude and an $8^{\circ} \mathrm{C}$ difference in annual mean temperature, but the difference in the fraction of active and diapausing females between these populations is relatively small. On the whole, females from all the three populations studied exhibit a weak response to photoperiod: under any photoperiodic regimen tested, more than half of the individuals do maturate over the course of the experiment (Fig, 2), and their maturation time is only weakly related to daylength (Fig. 3), whereas the previously studied native females from $\mathrm{Si}$ beria and the Far East maturate significantly faster under long-day conditions as compared with short-day conditions (Reznik and Vaghina, 2011, 2013; Reznik et al., 2015).

The northward expansion of invasive $H$. axyridis populations and their adaptation to colder climates seem to be accompanied by extremely hard selection: according to some data, winter mortality among adult beetles amounts to $99.8 \%$ (Sazhnev et al., 2020). Still, this invasive species shows almost no differences in photoperiodic responses over a broad climatic gradient, probably because its seasonal cycle remains relatively independent of daylength even at higher latitudes (Reznik et al., 2015). This would explain why our study discovered in the northern populations of the Asian ladybird only a minor increase in the tendency to enter diapause and only a slight delay in maturation.

\section{ACKNOWLEDGMENTS}

The authors are deeply grateful to B. A. Borisov (AllRussia Research Institute of Phytopathology, Moscow) and L.N. Bugaeva (All-Russia Research Institute of Biological Plant Protection, Krasnodar) who helped with collection of material and to L.S. Ramenskaya and T.Ya. Umarova for their help with experimental work.

\section{FUNDING}

The work was supported by Russian Science Foundation (grant no. 20-66-47010).

\section{COMPLIANCE WITH ETHICAL STANDARDS}

The authors declare that they have no conflict of interest. All the applicable international, national, and institutional guidelines for the care and use of animals were followed. All the procedures performed in studies involving animals were in accordance with the ethical standards of the institution or practice at which the studies were conducted.

\section{OPEN ACCESS}

This article is licensed under a Creative Commons Attribution 4.0 International License, which permits use, sharing, adaptation, distribution and reproduction in any medium or format, as long as you give appropriate credit to the original author(s) and the source, provide a link to the Creative Commons license, and indicate if changes were made. The images or other third party material in this article are included in the article's Creative Commons license, unless indicated otherwise in a credit line to the material. If material is not included in the article's Creative Commons license and your intended use is not permitted by statutory regulation or exceeds the permitted use, you will need to obtain permission directly from the copyright holder. To view a copy of this license, visit http://creativecommons.org/licenses/by/4.0/.

\section{REFERENCES}

Adriaens, T., San Martin y Gomez, G., and Maes, D., Invasion history, habitat preferences and phenology of the invasive ladybird Harmonia axyridis in Belgium, in From Biological Control to Invasion: the Ladybird Harmonia axyridis as a Model Species, Roy, H.E. and Wajnberg, E., Eds., Dordrecht: Springer, 2008, p. 69.

https://doi.org/10.1007/978-1-4020-6939-0_6

Andrianov, B.V., Blekhman, A.V., Goryacheva, I.I., Zakharov-Gezekhus, I.A., and Romanov, D. A., Aziatskaya bozhya korovka Harmonia axyridis: globalnaya invaziya (The Asian Lady Beetle Harmonia axyridis: a Global Invasion), Moscow: KMK, 2018.

Belyakova, N.A., Genetic heterogeneity and adaptive strategies of the lady beetle Harmonia axyridis Pall. (Coleoptera, Coccinellidae), Zh. Evol. Biokhim. Fiziol., 2011, vol. 47, p. 469.

Belyakova, N.A., Polymorphism of the lady beetle (Harmonia axyridis, Coleoptera, Coccinellidae) in the Baikal population, Zool. Zh., 2012, vol. 91, p. 961.

Belyakova, N.A. and Reznik, S.Ya., First record of the harlequin ladybird, Harmonia axyridis (Coleoptera: Coccinellidae) in the Caucasus, Eur. J. Entomol., 2013, vol. 110, no. 4, p. 699.

http://www.eje.cz/pdfs/110/4/699

Brown, P.M.J., Adriaens, T., Bathon, H., et al., Harmonia axyridis in Europe: spread and distribution of a non-native coccinellid, BioControl, 2008, vol. 53, no. 1, p. 5.

https://doi.org/10.1007/s10526-007-9132-y 
Brown, P.M., Thomas, C.E., Lombaert, E., Jeffries, D.L., Estoup, A., and Handley, L.J.L., The global spread of Harmonia axyridis (Coleoptera: Coccinellidae): distribution, dispersal and routes of invasion, BioControl, 2011, vol. 56, no. 4 , p. 623 .

doi: 10.1007/s10526-011-9379-1

Danilevskii, A.S., Fotoperiodizm i sezonnoe razvitie naseko$m y k h$ (Photoperiodism and Seasonal Development of Insects), Leningrad: Izd. LGU, 1961.

Danks, H.V., The elements of seasonal adaptations in insects, Can. Entomol., 2007, vol. 139, no. 1, p. 1.

https://doi.org/10.4039/n06-048

Denlinger, D.L., Regulation of diapause, Annu. Rev. Entomol., vol. 47 , p. 93.

https://doi.org/10.1146/annurev.ento.47.091201.145137

Dobzhansky, Th., Die geographische und individuelle Variabilitat von Harmonia axyridis Pallas in ihren Wechselbeziehungen, Biol. Centralblatt, 1924, vol. 44, no. 7, p. 401.

Esquivel, J.F., Improved visualization of fat body cell conditions and abundance in the southern green stink bug (Hemiptera: Pentatomidae), J. Entomol. Sci., 2011, vol. 46, no. 1, p. 52 .

doi: 10.18474/0749-8004-46.1.52.

Gao, Q., Wei, B.-X., Liu, W., Wang, J.-L., Zhou, X.-M., and Wang, X.-P., Differences in the development of internal reproductive organs, feeding amount and nutrient storage between pre-diapause and pre-reproductive Harmonia axyridis adults, Insects, 2019, vol. 10, no. 8, p. 243.

doi: 10.3390/insects 10080243

Goryacheva, I.I., and Blekhman, A.V., The genetic structure of native and invasive populations of Harmonia axyridis Pall. in the light of its global invasion, Genetika, 2016, vol. 52, p. 1358.

Hodek, I., Diapause / Dormancy, in Ecology and Behaviour of the Ladybird Beetles (Coccinellidae), Hodek, I., van Emden, H.F., and Honěk, A., Eds., Chichester: WileyBlackwell, 2012, p. 275.

Honěk, A., Brown, P.M.J., Martinkova, Z., et al., Factors determining variation in colour morph frequencies in invasive Harmonia axyridis populations, Biol. Invasions, 2020, vol. 22 , no. 6 , p. 2049.

https://doi.org/10.1007/s10530-020-02238-0

Khabibulin, A.F., Safina, I.I., and Khabibulin, V.F., To the coccinellid fauna (Coleoptera: Coccinellidae) of the industrial (northern) part of Ufa, Vestnik Mordov. Univ., Ser. Biol. Nauki, 2009, vol. 1, p. 74.

Kholin, S.K., Phenotypic variation of Harmonia axyridis Pall. in Primorskii Territory: geographic and chronological aspects. in Rol'nasekomykh v biotsenozakh Dal'nego Vostoka (The Role of Insects in the Biocenoses of the Far East), Arefin, V.S., Ed.,Vladivostok: DVO AN SSSR, 1988, p. 106.

Kholin, S.K., Stability of genetic polymorphism in the elytral color pattern of Harmonia axyridis Pall. (Coccinellidae, Coleoptera) in Primorskii Territory, Genetika, 1990, vol. 26, no. 12 , p. 2207.

Kono, Y., Change of photoperiodic sensitivity with fat body development during prediapause period in the twenty-eightspotted lady beetle, Henosepilachna vigintioctopunctata Fabricius (Coleoptera: Coccinellidae), Appl. Entomol. Zool., 1982, vol. 17, p. 92.

https://doi.org/10.1303/aez.17.92

Korotyaev, B.A., On high abundance of the Harlequin lady beetle Harmonia axyridis (Pall.) (Coleoptera, Coccinellidae) in the plains of the Northwestern Caucasus, Russia, Entomol. Obozr., 2013, vol. 92, p. 856.

Kruglova, O.Yu., Antonova, A.V., Klysheiko, Yu. I., and Silina, A. I., Monitoring of the phenotypic composition of invasive groupings of Harmonia axyridis (Pallas, 1773) in Belarus. in Transgranichnoe sotrudnichestvo $v$ oblasti ekologicheskoi bezopasnosti i okhrany okruzhayushchei sredy (Transborder Collaboration in Environmental Safety and Nature Conservation), Gusev, A.P., Ed., Homyel: GGU im. F. Skoriny, 2020, p. 167.

Lombaert, E., Guillemaud, T., Cornuet, J.M., Malausa, T., Facon, B., and Estoup, A., Bridgehead effect in the worldwide invasion of the biocontrol Harlequin ladybird, PloS ONE, 2010, vol. 5, no. 3, E9743.

https://doi.org/10.1371/journal.pone.0009743

Musolin, D.L., Surviving winter: diapause syndrome in the southern green stink bug Nezara viridula in the laboratory, in the field, and under climate change conditions, Physiol. Entomol., 2012, vol. 37, no. 4, p. 309.

https://doi.org/10.1111/j.1365-3032.2012.00846.x

Nekrasova, O.D. and Titar, B.M., Distribution, phenotypic habitus, and seasonal peculiarities of the invasive species Harmonia axyridis (Pallas, 1773) (Coleoptera: Coccinellidae) in the territory of Ukraine, Izv. Kharkov. Entomol. Obshch., 2016, vol. 24, no. 1, p. 22.

Obrycki, J.J., Comparative studies of reproductive diapause in North American populations of three Hippodamia species (Coleoptera: Coccinellidae), Environ. Entomol., 2020, vol. 49, no. 5, p. 1164.

https://doi.org/10.1093/ee/nvaa100

Obrycki, J.J., Orr, D.B., Orr, C.J., Wallendorf, M., and Flanders, R.V., Comparative developmental and reproductive biology of three populations of Propylea quatuordecimpunctata 
(Coleoptera: Coccinellidae), Biol. Control, 1993, vol. 3, no. 1, p. 27.

https://doi.org/10.1006/bcon.1993.1005

Ohashi, K., Kawauchi, S.E., and Sakuratani, Y., Geographic and annual variation of summer-diapause expression in the ladybird beetle, Coccinella septempunctata (Coleoptera: Coccinellidae), Appl. Entomol. Zool., 2003, vol. 38, no. 2, p. 187.

https://doi.org/10.1303/aez.2003.187

Orlova-Bienkowskaja, M.J., A dangerous invasive species of lady beetle Harmonia axyridis (Pallas, 1973) (Coleoptera, Coccinellidae) in European part of Russia, Ros. Zh. Biol. Invazii, 2013, vol. 1, p. 75 .

Orlova-Bienkowskaja, M.J., Mass reproduction of the lady beetle Harmonia axyridis (Pallas, 1973) (Coleoptera, Coccinellidae) in the Caucasus and possible sources of invasion, Ros. Zh. Biol. Invazii, 2014, vol. 3, p. 73.

Orlova-Bienkowskaja, M.J., Ukrainsky, A.S., and Brown, P.M., Harmonia axyridis (Coleoptera: Coccinellidae) in Asia: a re-examination of the native range and invasion to southeastern Kazakhstan and Kyrgyzstan, Biol. Invasions, 2015, vol. 17, no. 7, p. 1941.

https://doi.org/10.1007/s10530-015-0848-9

Osawa, N., The effect of prey availability on ovarian development and oosorption in the ladybird beetle Harmonia axyridis (Coleoptera: Coccinellidae), Eur. J. Entomol., 2005, vol. 102, no. 3 , p. 503.

https://doi.org/10.14411/eje.2005.072

Raak-van den Berg, C., Hemerik, L., de Jong, P.W., and van Lenteren, J.C., Mode of overwintering of invasive Harmonia axyridis in the Netherlands, BioControl, 2012, vol. 57 , p. 71.

https://doi.org/10.1007/s10526-011-9394-2

Reznik, S.Ya. and Vaghina, N.P., Photoperiodic control of development and reproduction in Harmonia axyridis (Coleoptera: Coccinellidae), Eur. J. Entomol., 2011, vol. 108, no. 3, p. 385.

http://www.eje.cz/pdfs/eje/2011/03/08.pdf

Reznik, S.Ya. and Vaghina, N.P., Effects of photoperiod and diet on diapause tendency, maturation and fecundity in Harmonia axyridis (Coleoptera: Coccinellidae), J. Appl. Entomol., 2013, vol. 137, no. 6, p. 452.

https://doi.org/10.1111/jen.12016

Reznik, S.Ya., Dolgovskaya, M.Yu., Ovchinnikov, A.N., and Belyakova, N.A., Weak photoperiodic response facilitates the biological invasion of the Harlequin ladybird Harmonia axyridis (Pallas) (Coleoptera: Coccinellidae), J. Appl. Entomol., 2015, vol. 139, no. 4, p. 241.

https://doi.org/10.1111/jen.12158

ENTOMOLOGICAL REVIEW Vol. 101 No. 62021
Reznik, S., Ovchinnikov, A., Ovchinnikova, A., BezmanMoseyko, O., and Belyakova, N., Photoperiodic, thermal and trophic responses of a predatory ladybird Cheilomenes propinqua, J. Appl. Entomol., 2021, vol. 145, nos. 1-2, p. 134.

https://doi.org/10.1111/jen.12833

Roy, H. and Wajnberg, E., From biological control to invasion: the ladybird Harmonia axyridis as a model species, BioControl, 2008, vol. 53, no. 1, p. 1.

https://doi.org/10.1007/s10526-007-9127-8

Roy, H.E., Brown, P.M., Adriaens, T., Berkvens, N., Borges, I., et al., The harlequin ladybird, Harmonia axyridis: global perspectives on invasion history and ecology, Biol. Invasions, 2016, vol. 18, no. 4, p. 997.

https://doi.org/10.1007/s10530-016-1077-6

Ruchin, A.B., Egorov, L.V., Lobachev, E.A., Lukiyanov, S.V., Sazhnev, A.S., and Semishin, G.B., Expansion of Harmonia axyridis (Pallas, 1773) (Coleoptera: Coccinellidae) to European part of Russia in 2018-2020, Balt. J. Coleopterol., 2020, vol. 20, no. 1, p. 51.

Sakurai, H., Kawai, T., and Takeda, S., Physiological changes related to diapause of the lady beetle, Harmonia axyridis (Coleoptera: Coccinellidae), Appl. Entomol. Zool., 1992, vol. 27 , no. 4 , p. 479.

https://doi.org/10.1303/aez.27.479

Saulich, A.Kh., Sezonnoe razvitie nasekomykh i vozmozhnosti ikh rasseleniya (Seasonal Development of Insects and the Possibilities for Their Dispersal), St. Petersburg: Izd. SPbGU, 1999.

Saulich, A.Kh. and Volkovich T.A, Ekologiya fotoperiodizma nasekomykh (Ecology of Insect Photoperiodism), St. Petersburg: Izd. SPbGU, 2004.

Saunders, D.S., Steel, C.G.H., Vafopoulou, X., and Lewis, R.D., Insect Clocks, Amsterdam: Elsevier, 2002.

Sazhnev, A.S., Anikin, V.V., and Zolotukhin, V.V., Overwintering and new records of invasive Harlequin ladybird Harmonia axyridis (Pallas, 1773) (Coleoptera: Coccinellidae) after mass expansion to European part of Russia in 20182019, Rus. J. Ecosystem Ecol., 2020, vol. 5, no. 4, p. 43. https://doi.org/10.21685/2500-0578-2020-4-4

Tan, C.C., Mosaic dominance in the inheritance of color patterns in the lady-bird beetle, Harmonia axyridis Pallas, Genetics, 1946, vol. 31, no. 1, p. 195.

Tauber, M.J., Tauber, C.A., and Masaki, S., Seasonal Adaptations of Insects, New York: Oxford Univ. Press, 1986.

Tougeron, K., Diapause research in insects: historical review and recent work perspectives, Entomol. Exp. Appl., 2019, vol. 167, no. 1, p. 27.

https://doi.org/10.1111/eea.12753 
Tyshchenko, V.P., Physiology of insect photoperiodism, Tr. Vses. Entomol. Obshch., 1977, vol. 59, p. 1.

Ukrainskii, A.S., The Asian ladybird Harmonia axyridis Pall. (Coleoptera, Coccinellidae) in Northern Caucasus, Evraziat. Entomol. Zh., 2013, vol. 12, p. 35.

Ukrainsky, A.S. and Orlova-Bienkowskaja, M.J., Expansion of Harmonia axyridis Pallas (Coleoptera: Coccinellidae) to European Russia and adjacent regions, Biol. Invasions, 2014, vol. 16, no. 5, p. 1003.

https://doi.org/10.1007/s10530-013-0571-3

Vaghina, N.P., The influence of photoperiodic conditions on the development of the ovaries in the Middle Asian population of Chilocorus bipustulatus L. (Coleoptera, Coccinellidae), Entomol. Obozr., 1974, vol. 53, p. 66.

Vinogradova, E.B., Diapauza mukh i eyo regulyatsiya (Diapause in Flies and Its Control), St. Petersburg: Nauka, 1991.

Vorontsov, N.N. and Blekhman, A.V., Phenogeography and genogeography of elytral coloration in the populations of the East Asian ladybird Harmonia (Leis) axyridis Pall. (Coleoptera, Coccinellidae), Doklady AN SSSR, 1986, vol. 286, p. 205.

Zakharov, I. A., Harmonia in Moscow, Priroda, 2015, vol. 11, p. 92.

Zakharov, I.A. and Romanov, D.A., Distribution and some biological peculiarities of the invasive species Harmonia axyridis in the Crimean Peninsula, Ros. Zh. Biol. Invazii, 2017, vol. 4, p. 54.

Zaslavskii, V.A., Geographical races of Chilocorus bipustulatus L. (Coleoptera, Coccinellidae). 1. Two types of the photoperiodic reaction that controls the imaginal diapause in the northern race, Zool. Zh., 1970, vol. 49, no. 9, p. 1354.

Zaslavskii, V.A., Fotoperiodicheskii i temperaturnyi kontrol razvitiya nasekomykh (Photoperiodic and Temperature Control of Insect Development), Leningrad: Nauka, 1984.

Zhivotovskii, L.A., Populyatsionnaya biometriya (Population Biometry), Moscow: Nauka, 1991. 